\title{
Muslim Ritual Practices and their Multilayered Mes- sages in a Non-Muslim Environment: Examples from the Dutch Context
}

\author{
HERMAN L. BECK \\ Tilburg University
}

\begin{abstract}
Many Muslims in the Netherlands want to live according to the prescriptions of their religion, but are trying at the same time to accommodate themselves to Dutch society in everyday life. Accommodation also seems to occur in the area of Muslim ritual practices, even though most orthodox and orthoprax Muslims are convinced of the 'unchangeability' of Islamic rituals. The study of Islamic rituals and changes in them in a non-Muslim Western environment have therefore become very popular among Western researchers. Most studies have focused on the relation between ritual, social cohesion and group identity. By focusing on certain Muslim ritual practices in the non-Muslim environment of the Netherlands, this article draws attention to the role of ritual as an expression of faith on part of the individual believer, thus stressing the multilayered messages conveyed by ritual practices.
\end{abstract}

Keywords: religious studies, rituals, Muslims in a non-Muslim environment

At the start of a course on 'The Ritualisation of Islam in the Netherlands', a Muslim student of Turkish origin asked me whether the course was not totally pointless. ${ }^{1}$ The central question of the course was the following: given the impact on both Christianity and Islam in the Netherlands of a variety of social and cultural factors - modernisation and secularisation, emancipation and feminism, religious pluralism and inter-religious contacts - are Muslim rituals in the Dutch context subject to change? If so, what is the cause of

1 In using the concept of ritualisation in the course, I more or less link up with Grimes' ritualizing: '... the activity of deliberately cultivating rites' (Grimes 1990, 10). 
these changes? What message or messages do these changes convey and what do they say about the spiritual life of Muslims in the Netherlands? The student seemed to take it for granted that Muslim rituals are unchangeable. As a practising believer within mainstream orthodox Sunni Islam, her question showed her conviction that the only rituals in Islam that matter are those that belong to the 'ibâdât, the ritual devotional prescriptions in Islam that regulate contacts between God and the individual. The 'ibâdât originate from the Qur'an and acquired their 'definitive', canonical form on the basis of the Sunnah, the Prophet Muhammad's normative example for Muslims. As a result, the 'ibâdât have been considered in Islamic law as 'direct expressions of faith', and have been an unchangeable constant through the ages down to the present day. ${ }^{2}$ The 'ibâdât include the ritual devotional prayer (salât), which must be performed five times a day at fixed times and in the prescribed manner; the 'religious tax' (zakât); fasting (sawm) during the month of Ramadan, with the accompanying 'feast of breaking the fast' ('îd al-fitr); and the pilgrimage to Mecca (hadjdj), with its 'feast of sacrifice' ('îd al-adhâa). Ritual devotional duties other than the 'ibâdât are not prescribed, and are therefore either unnecessary or 'innovations' (bid'a); they are not approved by orthodox or orthoprax Muslims, according to whom any change in, adaptation to, or omission in the ritual devotional rules is necessarily perceived as violating the provisions of Islamic law. Such changes are therefore sometimes also designated as 'heresy'. It must be noted, however, that according to the Islamic law on the 'ibâdât they serve a 'double' purpose: they are to be performed above all for the honour and glory of God, but simultaneously they strengthen the mutual brotherhood, solidarity, and unity of the umma, the Islamic religious community. In addition, Islamic law makes it clear that by performing the 'ibâdât Muslims distinguish themselves from non-Muslims.

\section{Ritual Studies and the 'Unchangeability' of Ritual Practices}

The view that Islamic ritual devotional actions are fixed for eternity as to form and content, and constitute 'unchangeable constants', because they are inseparably linked to faith and doctrine, contrasts sharply with the views of contemporary social scientists, theologians, and liturgists, who on the contrary emphasize the dynamic character of ritual actions and ritual practices. It is mainly cultural anthropologists, leaning on the results of

2 For a contemporary thinker, see for example the French imam Tareq Oubrou $(1998,34)$. 
field work, who have provided entirely new insights; not only into changes taking place within ritual practices - whether or not consciously introduced and cultivated by participants and/or certain authorities - but above all into the range of possible functions and meanings of ritual practices. Synthesis studies in the 1980s and 1990s, for example by William Doty and Catherine Bell, have attempted to map the various functions of ritual practices. ${ }^{3}$ These synthesis studies show an apparent general tendency among Ritual Studies specialists to locate the functions of ritual practices primarily in the field of social cohesion and (social, collective) identity.

This tendency has been further enhanced by the rise of Ritual Studies directed at multicultural Western societies. In this context, new research fields include multiculturalism, especially migration, and the resulting 'diaspora' situation of migrants; the likely minority position of migrants, and its consequences; contacts of migrants with other cultures and religions; and the 'sense of contrast ${ }^{\prime 4}$ bound up with this, leading to a life characterized by the 'duality of the diaspora between continuity and change' (Vertovec 2004, 285). In the field of rituals too, continuous dialectics exist between the changeable and the unchangeable - or, in the phrasing of Stewart and Strathern (2005, XVI), between 'fixity and fluidity'. Probably also inspired by communication sciences, and influenced by the idea of ritual as a form of 'symbolic communication', the study of rituals in a multicultural and religiously pluralist context has led to the important insight that the 'other' or 'outsider' can be just as meaningful for a ritual as the 'participant' or 'insider'. Developments and changes in ritual practices in a multicultural, religiously pluralist context can take place particularly with a view to the 'other' or 'outsider' (Baumann 1992). At the same time, it is emphasized that in the case of Muslims living in a Western, multicultural, religiously pluralist context, meeting and competing with the 'Muslim other' is at least equally important for social cohesion among Muslims, and an own identity, as is confronting and competing with the 'non-Muslim other' (Eickelman \& Piscatori 1990, XV). This may also be expressed in the form and content given to ritual practices, which are always understood in terms of an interpretation framework wherein

3 Doty (1986, 104ff; 2000, 398ff) distinguishes twelve to thirteen functions of rituals. Bell (1997, 89) postulates a division into three main functions: 'Ritual as the expression of paradigmatic values of death and rebirth; ritual as a mechanism for bringing the individual into the community and establishing a social entity; or ritual as a process for social transformation, for catharsis, for embodying symbolic values, for defining the nature of the real, or for struggling over control of the sign.'

4 The term 'sense of contrast' was coined by Metcalf $(1996,7)$. 
the concepts of social cohesion and (social, collective) identity are central in one way or another.

\section{Research Question}

While I am all for theologians, liturgists, and religious scientists using the results of research approaches by social scientists, as described above, a caveat is in order here. Martin Baumann $(1998,95)$ has criticized most diaspora studies because only marginal attention is paid to religion, while the emphasis is on such themes as ethnicity and nationality. In the same vein, I will argue that the focus on rituals, ritual acts, and ritual practices as primarily serving social cohesion and (social, collective) identity threatens to diminish and belittle the meaning of the faith of the individual performing a ritual or acting ritually, by undervaluing the ritual as an expression of faith. Without wishing to detract in any way from the great value and indispensable contributions of social science research, I hope in this contribution to persuade theologians, liturgists, and scholars of religion that, given their special knowledge in the fields of faith and religion, they are required to test, evaluate and adapt or fine-tune the results of social science research in applying them in their own field. In conducting research in the field of Ritual Studies, theologians, liturgists, and scholars of religion should give more scope to the classic insight that rituals are also forms whereby the believer, both as an individual and as a member of a collective, gives expression to his/her faith and belief.

In the following I discuss two examples of Islamic ritual practices, along with possible adaptations/changes in these practices resulting from the sojourn of the Muslims conducting these rituals in a multicultural, religiously pluralist, Dutch context. On the basis of this discussion, I argue that these adaptations/changes in the ritual field certainly have to do with social cohesion and identity, but must also be interpreted in the light of the belief(s) of the Muslim as both an individual and a member of a group, and can be understood as an expression of faith. Before presenting the examples, I offer some general information regarding the presence of Muslims in the Netherlands and the influences and processes to which they are exposed.

\section{Muslims in the Netherlands}

Islam in the Netherlands covers a colourful spectrum. Those who practise it are from various countries of origin and differ in ethnicity, denomination, 
and motives for coming to the Netherlands. What many Muslims in the Netherlands have in common, however, is that (1) in one way or another they acknowledge Islam as an established tradition and as an important framework of reference; (2) they must live with the fact that their religion is a minority religion, lacking the dominance in the public sphere that is taken for granted in their country of origin; (3) they are confronted, much more strongly than in their country of origin, with the many possible ways of being a Muslim, thus experiencing their religion as a mosaic rather than as a monolithic, invariable unity. ${ }^{5}$

The sojourn in the Western, multicultural, religiously pluralist and secularized world, the worldwide contacts between Muslims, and the influence - by means of modern communication technologies - of all kinds of trans(multi)national Muslim networks have led, among Muslims as well, to a process which the Flemish economic geographer Erik Swyngedouw has called glocalization. Swyngedouw defines glocalization as a process whereby global integration goes hand in hand with local differentiation, polarisation and exclusion. ${ }^{6}$ Thus glocalization consists of the two contradictory processes of globalisation and localisation. As a result of the globalisation process of Islam, Muslims feel increasingly strongly connected to the global umma, and they 'discover' the 'universals', the absolute religious truths and religious practices, of their faith. The researcher Camilla Gibb, for example, is convinced that the process of globalisation will lead to a 'homogenisation' or 'essentialisation' of Muslim (ritual) practices, whereby national or regional traditions will give way to 'normative' (ritual) practices based on the Qur'an and the Sunnah (as cited in Vertovec 2004, 292f.). The process of localisation is characterised by the development of a local variant of Islam, whereby either local cultural traditions from the country of origin play a typifying role, or adaptations or new creations evolve under the influence of the culture of the new country of residence. The localisation of Islam may lead to differentiation, polarisation, and mutual exclusion among Muslims. There is tension between globalisation and localisation, both of which impact the way in which Muslims give form and content to their religion and their rituals in their new country of residence.

5 The image of the 'mosaic' in this framework is derived from Gregorian 2003.

$6<$ http://www.archined.nl/archined/3178.html> and <http://www.landwerk.nl/Artikelen/ artikel-platbroeken.htm $>$ (both in Dutch), accessed on 18 August 2006.

I would like to thank the anonymous reviewer who drew my attention to the fact that the sociologist of religion Roland Robertson was among the first scholars to apply the concept of glocalization in English, in his book Globalization: Social Theory and Global Culture. London: Sage Publications, 1992. 
The globalisation and localisation of Islam are processes that may have an impact on changes in or adaptations to rituals. In my opinion, these concepts are applicable, in combination with Dessing's two categories of change, to studies which explore the function(s) of rituals, especially those of Muslims, in a multicultural, religiously pluralist context like the Dutch one. In the framework of her $\mathrm{PhD}$ research, Nathal Dessing has conducted a pioneering study of life-cycle rituals among Muslims in the Netherlands (Dessing 2001). Dessing's distinction between two categories of potential change that can take place in these life-cycle rituals is important for the present analysis:

As a rule, two types of change can be distinguished in life-cycle rituals among Muslims in the Netherlands. Internal changes are changes that are inherent in the transplantation of rituals into a new context, such as the reduction in size and variety of the ritual repertoire and the reduced competence of the ritual actors. External changes are those that are imposed by the Dutch social and legal context, such as different laws in the field of marriage and funeral arrangements, limited access to services that are widely available in the country of origin, different living conditions, and climatic circumstances. (Dessing 2001, 213; translated from the Dutch summary.)

Swyngedouw's glocalization thesis and Dessing's two categories of change can be helpful in studying, understanding, and explaining change(s) and/ or adaptations in the ritual practices of Muslims in the Netherlands. They offer insight into the cause or causes underlying any changes in these ritual practices. Modifications may be motivated by a wish to make the changed or adapted ritual practice serve social cohesion and/or identity, as emphasized by social scientists. I therefore argue, on the basis of two examples of ritual practices, in favour of paying more attention to the role of the faith and belief of the Muslim, both as an individual and as a member of a group, in changes or adaptations in ritual practices. The two ritual practices analyzed here more closely are those concerning (1) ritual purification and (2) fasting during the month of Ramadan.

\section{Example 1: Ritual Purification}

In many religions, ritual purification is an extremely important concept. Since Mary Douglas' Purity and Danger: An Analysis of Concepts of Pollution and Taboo of 1966, many social scientists have considered purification provisions 
as symbolic classification systems by means of which a society structures reality. Following this research, purification has also been studied as an element in and aspect of communication (see e.g. Bendlin 1998). In Islam in particular, the correct intention and a ritually pure state are preconditions for the worship of God. Ritual purification (tahâra) is therefore the presupposition of and precondition for the valid execution of ritual devotional rules - which, after all, regulate contact between human beings and God.

At the beginning of the 1990s, the anthropologist Yvon Bartelink conducted research for her PhD thesis Vrouwen over Islam (Women about Islam), studying the religious images and practices of a core group of nine Muslim women and a larger 'control group' of more than sixty Muslim women (Bartelink 1994, 17). Both groups consisted of Muslim women of Moroccan origin, living in the Dutch province of Brabant. Bartelink divided the nine women of the core group, based on their style of faith, into three categories: conservative (4), scriptural (2), and liberal (3). (Bartelink 1994, 209.) The point of departure in Bartelink's study was the view that institutionalized Islam is an Islam of men, while women practise their religion in a less visible and less formal way. Her aim was to supplement the one-sided emphasis on dominant Islam by drawing attention to the views and experiences of Moroccan Muslim women (Bartelink 1994, 7 f.), who derive strength from their religion and who give shape to it creatively in their everyday activities. Bartelink was mainly interested in the relationship between the women's twofold identities: as Muslim and as women (Bartelink 1994, 2).

Part of Bartelink's PhD research was devoted to the practical approach of the Muslim women she interviewed to the regulations concerning ritual purification in a multicultural, religiously pluralist society such as that in the Netherlands, and how they thought about this. In this context, she referred regularly to Douglas. The women in Bartelink's study viewed Islam and purity as inseparably linked: Islam without purity is unthinkable and impossible. (Bartelink 1994, 63.) The women therefore considered purification and the way they dealt with it as an essential characteristic of Islam. It serves not only to mark the distinction between Muslims and non-Muslims - an aspect that in Morocco, their country of origin, was hardly relevant if at all, and did not become meaningful until they came to the Netherlands - but also to distinguish between Muslim men and Muslim women, and among Muslim women. (Bartelink 1994, 72.) Ritual purification, in Bartelink's study, is therefore an identity marker in three ways: (a) between the ingroup of the umma (the Islamic religious community) and the outgroup of non-Muslims; (b) between women and men; and (c) among women within 
the ingroup. It is clear that Bartelink, as a cultural anthropologist, attaches great value to understanding ritual purification practices in the function of social cohesion and identity.

Some additional comments on Bartelink's study may be useful. First of all, the state of ritual purity as a way to mark the difference between Muslims and non-Muslims is related not only to the individual's physical state, but also to food and other material issues and to spaces. Bartelink, for instance, mentions that the women did not let her touch the Qur'an; they were concerned that she might be having her period and would therefore be ritually unclean. For the same reason, they did not admit her to the washing area or the prayer hall of the Islamic centre that she visited. Other studies show that Muslims also attach the concept of ritual purification to their home, which in a Western, secularised context is pre-eminently the location for the daily religious practices of the Muslim. The ritually clean dwelling - just like the ritually clean body - expresses the Muslim identity; the dwelling is distinct and separate from the outside world, which is unclean and non-Muslim. (Mazumdar \& Mazumdar 2005, 128 f.)

Bartelink also pays attention to the concept of ritual purity as on the one hand a means of power for men, on the other a strategic tool for women. Men also owe their superior position as regards women to the feelings and prescriptions concerning ritual purification, since women are more often impure as a result of their physical condition. Women, however, can make strategic use of the feelings and prescriptions concerning ritual purification. The anthropologist Marjo Buitelaar (2006, $189 \mathrm{ff}$.) mentions that women in Morocco sometimes use the following argument to refuse their husbands sex: sexual intercourse makes a woman unclean, and if she does not have the opportunity to go to the bathhouse she cannot fulfil her ritual devotional duties.

In the Netherlands, where every house has facilities for ritual ablution, such an argument does not hold. Bartelink's observation is therefore interesting: the conservative women whom she interviewed said that they could not achieve the right state of ritual purity because of the lack of bathhouses in the Netherlands, while women who were more scripturally inclined indicated that their study of the Qur'an had led them to realise that the bathhouse is not an Islamic institution and is therefore not necessary for ritual purification. (Bartelink 1994, 80 f.) Bartelink's study does not elaborate on whether, apart from the lack of bathhouses in the Dutch context - a clear example of what Dessing calls an 'external change' - other changes or adaptations had taken place in the devotional practice of ritual purification. The pro- 
cesses of globalisation and localisation, however, do seem to play a role. Localisation was apparent among conservative women, who attributed a central role to the bathhouse in achieving a ritually clean state. Scripturally inclined women, as well as more liberal ones, were under the influence of the worldwide tendency among Muslims to return to the Qur'an and Sunnah, as primary sources and supreme authorities, as points of departure for their faith and their lives. Local traditions like the bathhouse, which do not have a basis in the Qur'an or the Sunnah, are then easily given up.

It is remarkable that the women of all three denominations experienced ritual purity and the related ritual practices more strongly as an essential prerequisite for the worship of God than as a distinguishing mark between Muslims and non-Muslims, between men and women, and among women. They experienced their recurring state of impurity as an exercise in patience (sabr), one of the most important notions in the Islamic faith; it was something that God required of them and for which they would be rewarded on the Day of Judgment. Bartelink's study seems to be pointing in the direction of the primacy of rituals as a way to express faith and belief over their function in promoting social cohesion and identity.

\section{Example 2: Fasting During the Month of Ramadan}

One of the ritual religious duties in Islam is fasting during the month of Ramadan. Through fasting, the Muslim expresses his/her gratitude to God for sending down the revelations of the Qur'an, the greatest gift of grace which God has given mankind. Fasting has both an external and an internal dimension (Ashraf 1989). The external dimension of fasting is the physical, ritual devotional act of abstaining from food, drink, and sexual intercourse during the entire time of daylight. The internal dimension of fasting is the mental, spiritual act whereby the fasting person feels stimulated to remain far from everything which, according to Islam, is negative or bad. Reciting specified parts of the Qur'an on each of the thirty days of Ramadan emphasizes this gratitude and is considered to be a pre-eminently positive act, because it helps the Muslim to focus on God. The month of fasting is also characterized as a time which strengthens social contacts and a sense of solidarity: there is an obligation to pass on the benefits received from God to one's neighbours. This is expressed symbolically in the ritual devotional practice of zakât al-fitr, 'charity on the occasion of ending the fast'.

For Muslims in the Netherlands, there are no legal provisions forming an impediment to performing the ritual devotional duty of fasting during 
the month of Ramadan. Still, Muslims experience the observance of rituals in a Western, multicultural, religiously pluralist, secularized country like the Netherlands as problematic. In their country of origin, the whole month of Ramadan had been experienced as a festive month of 'time out of time', with a clear dimension of contrast: ${ }^{7}$ during Ramadan, daylight is a time of fasting, while 'normal' life is lived at night, after breaking the fast, and is characterized by a great sense of community, expressed in such social activities as shared meals, family visits, etc. Buitelaar $(1991 ; 1993)$ therefore refers to Ramadan as the month of fasting and feasting.

Research by the anthropologist Karin van Nieuwkerk (2003), among thirty Muslim women of Moroccan origin living in the Netherlands, indicates that the absence of this sense of 'time out of time' during Ramadan is for them the most important difference between fasting during Ramadan in their country of origin and in the Netherlands: it is business as usual at the children's school and the husbands' place of work (unless they take time off). This lack of opportunity to share the atmosphere of Ramadan with family and friends, which is so characteristic of the month of fasting, is also keenly felt because of the physical absence and logistic distance of their loved ones. The physical environment feels wrong: the streets are not filled with the smell of harira, the soup with which the fast is broken at night. The adhân, the call that summons people to prayer, is not heard in Dutch towns, with the exception of a few cities where an exemption has been granted by the municipal authorities for the call to Friday afternoon prayers. The 'îd al-fitr, the festival of ending the fast, is not celebrated as exuberantly or in the same public way as in the country of origin. There is uncertainty as to whom the zakât al-fitr should be given to, since genuinely poor and needy people are few and far between. Sending the zakât al-fitr to the country of origin, to be divided there, is not felt to be quite satisfactory either. In short, fasting during the month of Ramadan in the Dutch context has been subject to a number of internal and external changes, as a result of which the genuine 'Ramadan feeling' of the country of origin has been lost.

The impact of globalisation is shown by the fact that, more than in the country of origin, Muslims in the Netherlands experience solidarity in fasting with all brothers and sisters in the faith in the rest of the world. Studies strikingly show that the fast is observed by a very high percentage of Muslims in the Netherlands - including young people, whether practising Muslims or otherwise, and despite external circumstances which make

7 The idea of the festival as 'time out of time' is derived from Falassi (1987). 
fasting relatively difficult. ${ }^{8}$ Fasting during Ramadan distinguishes Muslims from non-Muslims, and is thus a distinguishing mark of identity for the Muslim, who feels solidarity with all other fasting Muslims.

The process of localisation seems to emerge where determining the end of the month of fasting is concerned. In the Netherlands it is considered to end at different times, depending on whether a Muslim group adheres to the practice in the country of origin or adopts the choice offered by Islamic law, between 'the sighting of the new moon' and 'calculation'; this is one marker of the difference between traditionalist and modernist Muslims. In particular the cultivation by certain Muslim groups of strict adherence, where the end of the fast is concerned, to the traditions of the region of origin could be interpreted as indicating a process of localisation; by this means, the relevant group of Muslims wishes to explicitly distinguish itself from other Muslim groups.

A new initiative in the Netherlands in the context of fasting during the month of Ramadan was the establishment of the National Iftar and Dialogue Meeting by the Islam and Citizenship Foundation (Stichting Islam en Burgerschap). ${ }^{9}$ The Foundation was established already in 1999, as a citizens' initiative to start up the debate on norms, values and citizenship, and the role that Islamic organisations can play in this context. In addition, the Islam and Citizenship Foundation wanted to fulfil a bridging function within the Islamic community, between Islamic organisations and the rest of the Dutch community, and between Muslims and non-Muslims in general. Finally, the Foundation saw a role for itself in stimulating inter-religious contacts and dialogue among the various communities in the Netherlands.

With a view to this bridging function between Muslims and non-Muslims, the Islam and Citizenship Foundation introduced the annual National Iftar and Dialogue Meeting in 2001. The iftâr is a meal - usually within the family or a circle of Muslim friends - eaten daily during Ramadan, right after sunset, to break the daily fast. In the Islamic heartlands it is very common to

8 Phalet \& Ter Wal 2004, 11: on average, 80 per cent of the Turkish Muslims in Rotterdam fasted throughout the entire month (77.2 per cent of young people, 82.5 per cent of the older people); of the Moroccan Muslims, on average 94.2 per cent fasted (91.6 per cent of the young and 96.5 per cent of the older people). See also e.g. Nabben et al. 2006, 71.

9 At the local level, various initiatives already existed to establish contacts between the Muslim and Dutch communities by means of joint iftar celebrations with non-Muslims. For example, certain Islamic student associations but also the Milli Görüs organised such meals upon breaking the fast. See e.g. Boender 2007, 118, 231.

However, attention should also be paid to the fact that some groups of Muslims in the Netherlands consider the iftâr meals as the occasion par excellence 'to be among Muslims' only, thus experiencing relief from 'the always pressing duty of accommodation and integration'. 
organize iftâr meals for the poor and wanting, or for whole neighbourhoods. In a country like Egypt Muslims sometimes invite Copts to participate in the iftâr meal in order to share the joy of Ramadan. Apparently taking over this idea of sharing the iftâr meal with fellow citizens from other parts of the Islamic world, the Islam and Citizenship Foundation organised the National Iftar as a shared meal, approximately halfway through Ramadan, in which Muslims and non-Muslims, ordinary citizens and representatives of Muslim organisations and other religious, ideological, and social organisations could participate in an informal atmosphere. The meal, breaking the fast of that day, is followed by a discussion on a relevant social theme. So far, the National Iftar and Dialogue Meeting has always been held in one of the larger cities. The Islam and Citizenship Foundation organises the Iftar in cooperation with the authorities of the city in which the event takes place and with local, regional, and national Muslim organisations. ${ }^{10}$ In 2005, the National Iftar and Dialogue Meeting was organised as part of the first Ramadan Festival in The Hague; this was a project consisting of various activities, lectures, and debates, giving Muslims and non-Muslims an opportunity to meet. ${ }^{11}$ The Islam and Citizenship Foundation was discontinued on 1 January 2008, due to termination of government subsidies; the Ramadan Festival Foundation, founded in 2005, has apparently taken over the initiative of organising the yearly national iftâr meals. In 2009 and 2010, however, the Ramadan Festival seems to have focused less on (inter-religious) dialogue than on cultural and artistic manifestations.

The National Iftar and Dialogue Meeting and the Ramadan Festival are new developments in the Dutch context of the ritual practice of fasting during the month of Ramadan. ${ }^{12}$ One of the aims of the organisers of the two events was to promote opportunities for Muslims of different denominations and for Muslims and non-Muslims to meet. The National Iftar and Dialogue Meeting and the Ramadan Festival might therefore be interpreted as additions to the ritual practice of fasting during the month of Ramadan, resulting from internal and external changes and aimed at promoting social cohesion both in Dutch society as a whole and among the various Muslim communities in the Netherlands. A second way to interpret the National Iftar and Dialogue

10 Information derived from <http://www.islamenburgerschap.nl $>$ (in Dutch), accessed 11 August 2006.

11 Information derived from <http://ramadanfestival.nl $>$ (in Dutch), accessed 11 August 2006.

12 In the United States, opportunities offered by the iftar in a non-Muslim context have been explored by Muslims for some time now: not only for contacts with non-Muslims but also for example as a form of charity aimed at feeding the needy. See e.g. Smith 1999, 17. 
Meetings and the Ramadan Festival is that those Muslims who organise and participate in them are using them to communicate a message concerning their identity. They consider themselves to be Muslims who want to live in the Netherlands as Dutch citizens, and who therefore favour good contacts with their Dutch non-Muslim fellow-citizens. This attitude can be seen as an effect of globalisation. After all, everywhere in the Western world Muslims increasingly view themselves both as Muslim and as Dutch or German, English, French or whatever (cf. Eade 1996, 231).

Thirdly, in the case of the National Iftar and Dialogue Meetings, the initiators and later board members of the Islam and Citizenship Foundation were all Muslims who were 'successful' in Dutch society. They all had good jobs and occupied a number of important social positions. It is possible that in setting up the Islam and Citizenship Foundation they were not actuated by purely idealistic motives alone; through the Foundation, they may have hoped to obtain more political power and influence for Muslims in general and for themselves in particular. After all, the Dutch government had been hoping for decades to have an organisation of Muslims available which, among other things, would try to make Dutch norms and values a subject of discussion among Muslims and break down the barriers between the various Muslim denominations in the Netherlands. The annual subsidy from the Ministry of Justice for the Islam and Citizenship Foundation should also be understood in this context. This may well constitute a factor in the process of localisation.

A fourth interpretation focuses on the faith and belief of the organisers and participants in the National Iftar and Dialogue Meeting and the Ramadan Festival as individuals and as members of particular denominations. They believe that Islam is the peaceful and harmonious religion of the middle way, ${ }^{13}$ the adherents of which prefer good and peaceful relations with non-Muslims - as long as the latter do not treat Muslims with discourtesy. Organising and participating in the celebration of the national iftâr and the Ramadan festival are ways to express this conviction. Muslims with such beliefs distinguish themselves from those Muslim groups in the Netherlands which, on religious grounds, avoid contact with people of other creeds and confessions. Among these more separate groups, the celebration of Muslim rituals with non-Muslims is considered a bid'a and is therefore seen as absolutely wrong.

13 For the function of religion in general and of Islam in particular in the service of a harmonious society, see e.g. Beck 2002. 


\section{Some Concluding Remarks}

Various other ritual practices of Muslims in the multicultural, religiously pluralist context of the Netherlands indicate that the faith and belief of the Muslim as an individual and as a member of a particular group is expressed in the way the rituals are performed. In other words, one of the functions of rituals is the expression of individual belief. One example is the ritual meaning of the headscarf. In the Netherlands, as in other Western countries, wearing this ritual piece of clothing is becoming increasingly popular, especially among more highly educated women. When asked, they said that it was their belief in, respect for, and obedience to God that had prompted them to wear it. Pressure from the husband or from people around them, solidarity with Islam, the marking of a particular religious or social identity, or emancipatory purposes were only secondary motives or played no role at all. (Wiegers \& Beck 2005, 141ff; Beck \& Wiegers 2008.)

Now, what about the Muslim student whose reaction induced me to write this article to begin with? She herself qualifies as an example of the function of rituals as a way to express individual belief. She sees herself as a practising believer within the orthodox mainstream of (Turkish) Sunni Islam. With regard to Muslim fellow students who did not observe such ritual practices as fasting in the same way as herself during the month of Ramadan, or who did not abide by the rules concerning ritual purification, she more than once aired her opinion that they were not 'real' Muslims. On the other hand, she was one of the few Muslim students who attended the church funeral of one of the lecturers at Tilburg University; she was also the only Muslim to participate in the Eucharist. Traditionally, Islamic scholarship has explicitly and emphatically prohibited participation by Muslims in Christian rituals (Beck 2001). When asked about her conduct, she replied that she believed Islam to be a religion that teaches respect for and solidarity with a person who has died. She wished to express that conviction by attending the church service and participating in the celebration of the Eucharist.

Muslim ritual practices, just like ritual practices in other religions, have many functions and convey multi-layered messages. They may be aimed at social cohesion and identity. They may be employed as a way to achieve power or as a strategic tool to realize a certain objective. As a means of communication, they may convey various messages. Ritual practices can have many other functions and meanings, but in the multicultural, religiously pluralist context of the Netherlands, where 'the other' may be Muslim but also non-Muslim, ritual practices can have the primary function of expressing individual belief, not only towards non-Muslim others but especially 
towards Muslim ones. Dutch Muslims turn out to be subject to the process of modernisation to the same extent as the non-Muslim Dutch. For them too, its influence is perceptible in the differentiation and individualisation of experiencing and practising their religion in general and their rituals in particular. It is the special responsibility of the scholar of religion within the field of Ritual Studies to continue to draw attention to the fact that ritual practices are also a way to express individual belief.

\section{Bibliography}

\section{Ashraf, Syed Ali}

1989 The Inner Meaning of the Islamic Rites: Prayer, Pilgrimage, Fasting, Jihâd. - Seyyed Hossein Nasr (ed.), Islamic Spirituality: Foundations, 111-30. London: SCM Press.

\section{Bartelink, Yvon}

1994 Vrouwen over Islam. Geloofsvoorstellingen en -praktijken van Marokkaanse migrantes in Nederland (Brabant). PhD thesis, Katholieke Universiteit Nijmegen.

\section{Baumann, Gerd}

1992 Ritual Implicates 'Others': Rereading Durkheim in a Plural Society. - Daniel de Coppet (ed.), Understanding Rituals, 97-116. London \& New York: Routledge.

\section{Baumann, Martin}

1998 Sustaining 'Little Indias': Hindu Diasporas in Europe. - G. ter Haar (ed.), Strangers and Sojourners. Religious Communities in the Diaspora, 95-132. Leuven: Peeters.

\section{Beck, Herman L.}

2001 Christmas as Identity Marker. Three Islamic Examples. - P. Post \& G. Rouwhorst \& L. van Tongeren \& A. Scheer (eds), Christian Feast and Festival. The Dynamics of Western Liturgy and Culture, 97-110. Leuven: Peeters.

2002 A Pillar of Social Harmony: The Study of Comparative Religion in Contemporary Indonesia. - Gerard Wiegers (ed.), Modern Societies and the Science of Religions, 331-48. Leiden: Brill.

\section{Beck, Herman \& Gerard Wiegers}

2008 Moslims in een westerse samenleving. Islam en ethiek. Zoetermeer: Meinema. 


\section{Bell, Catherine}

1997 Ritual Perspectives and Dimensions. Oxford and New York: Oxford University Press.

\section{Bendlin, Andreas}

1998 Reinheit/Unreinheit. - Hubert Cancik \& Burkhard Gladigow \& KarlHeinz Kohl (eds), Handbuch religioswissenschaftlicher Grundbegriffe, IV 412-6. Stuttgart: Kohlhammer Verlag.

\section{Boender, Welmoet}

2007 Imam in Nederland. Opvattingen over zijn religieuze rol in de samenleving. Amsterdam: Bakker.

\section{Buitelaar, Marjo}

1991 Fasting and Feasting in Morocco. An Ethnographic Study of the Month of Ramadan. PhD thesis, Katholieke Universiteit Nijmegen.

1993 Vasten en feesten in Marokko: hoe vrouwen Ramadan vieren. Amsterdam: Bulaaq.

2006 Islam en het dagelijks leven. Amsterdam \& Antwerpen: Atlas.

\section{Dessing, Nathalia Maria}

2001 Rituals of Birth, Circumcision, Marriage, and Death among Muslims in the Netherlands. Leuven: Peeters.

\section{Doty, William G.}

1986/2000 Mythography. The Study of Myths and Rituals, Tuscaloosa \& London: University of Alabama Press.

\section{Eade, John}

1996 Nationalism, Community, and the Islamization of Space in London. - Barbara Daly Metcalf (ed.), Making Muslim Space in North America and Europe, 217-33. Berkeley: University of California Press.

\section{Eickelman, Dale F. \& James Piscatori}

1990 Preface. - Dale F. Eickelman \& James P. Piscatori (eds), Muslim Travellers. Pilgrimage, Migration and the Religious Imagination, XII-XXII. London: Routledge.

Falassi, Alessandro (ed.)

1987 Time out of Time. Essays on the Festival. Albuquerque: University of New Mexico Press.

\section{Gregorian, Vartan}

2003 Islam: A Mosaic, not a Monolith. Washington DC: Brookings Institution Press.

\section{Grimes, Ronald L.}

1990 Ritual Criticism. Case Studies in Its Practice, Essays on Its Theory. Columbia, South Carolina: University of South Carolina Press. 


\section{Mazumdar, Shampa \& Sanjoy Mazumdar}

2005 The Articulation of Religion in Domestic Space: Rituals in the Immigrant Muslim Home. - Pamela J. Stewart \& Andrew Strathern (eds), Contesting Rituals. Islam and Practices of Identity-Making, 125-45. Durham NC: Carolina Academic Press.

\section{Metcalf, Barbara Daly}

1996 Introduction. - Barbara Daly Metcalf (ed.), Making Muslim Space in North America and Europe, 1-27. Berkeley etc: University of California Press.

Nabben, Ton \& Berfin Yesilgöz \& Dirk J. Korf

2006 Van Allah tot Prada. Identiteit, leefstijl en geloofsbeleving van jonge Marokkanen en Turken. Utrecht \& Rotterdam: Forum.

\section{Nieuwkerk, Karin van}

2003 Migrating Islam. Changing Religious Celebrations among Moroccan Immigrant Women in the Netherlands. Unpublished paper presented at the LISOR conference in Leiden, 28-30 August 2003.

\section{Oubrou, Tareq}

1998 Introduction théorique à la charî́a de minorité. - Islam de France 2, $27-41$.

Phalet, Karen \& Jessika ter Wal (eds)

2004 Moslim in Nederland. Deel c: Religieuze dimensies, etnische relaties en burgerschap: Turken en Marokkanen in Rotterdam. Den Haag: Sociaal en Cultureel Planbureau.

\section{Smith, Jane I.}

1999 Islam in America. New York: Columbia University Press.

\section{Stewart, Pamela J. \& Andrew Strathern}

2005 Introduction. - Pamela J. Stewart \& Andrew Strathern (eds), Contesting Rituals. Islam and Practices of Identity Making, XV-XX. Durham NC: Carolina Academic Press.

\section{Vertovec, Steven}

2004 Religion and Diaspora. - Peter Antes \& Armin W. Geertz \& Randi R. Warne (eds), New Approaches to the Study of Religion, Volume 2: Textual, Comparative, Sociological and Cognitive Approaches, 275-303. Berlin \& New York: De Gruyter.

\section{Wiegers, Gerard \& Herman Beck}

2005 Religie in de krant. Een eerste kennismaking met de godsdienstwetenschap. Nijmegen: Valkhof Pers. 
